As one of the first pupils of Sommerfeld at Munich, Hopf graduated in 1909 with a thesis on the problem of turbulent flow in a river. He worked in particular on the influence of the roughness of the walls of a canal on the transition from laminary to turbulent flow. This work brought him into contact with the Mittlere Isar water regulation and drainage scheme, to which he was scientific adviser for several years. During the War of 1914-18, Hopf did valuable work on problems of stability of aeroplanes, and his collaboration with R. Fuchs led to their well-known monograph on aerodynamics. In the second edition (1934) the book was divided into three volumes, Hopf being responsible for the first, which dealt with general principles. This is still being used as the chief text-book for aeroplane designers in Germany.

In the early days of relativity and of quantum theory, Hopf collaborated with Einstein (1910-11). Several papers on radiation dating from that time, and a recent well-written popular account of matter and radiation (Springer, 1936) bear witness to his interest in this subject. More recently, Hopf studied the methods of solving linear differential equations in separate domains with the view of finding the relation between the corresponding solutions. A first paper appeared in 1935, and important applications to physical problems were to follow. The many friends of this genial and kind-hearted mathematician will deeply regret the loss they have suffered.

\section{Prince Ginori-Conti}

When Prince Piero Ginori-Conti died on December 9, Italy lost one of her most energetic industrial personalities and international science a devoted supporter. His name will always be associated with the industrial utilization of the volcanic springs in the Lardarello district of Tuscany. Thanks to his 'drive' and business acumen, these waters were made to generate electric current for transmission to Florence and Pisa, and to yield boric acid, carbon dioxide, etc., for industrial use. In the chemical works connected with this great undertaking, he was much helped by Prof. R. Nasini, and on the engineering side his son, Dr. Giovanni, one of the three children by his first wife, was of great assistance. An article on the Lardarello development appeared in NATURE of January 14, 1928, p. 59.

Ginori-Conti was born in 1865 as a scion of two ancient Italian families, Ginori and Conti, and on the latter side he claimed relationship with the Scottish Mackenzies. His title of Prince of Trevignano was inherited; that of Senator was granted him later in life. His first wife was the daughter of the Count of Lardarel, the owner of the springs, and his second wife was a French lady. A charming personality, Prince Ginori-Conti came frequently to London where, as a member of the executive committee of the Union Internationale de la Chimie, and as an honorary member of the Society of Chemical Industry, his visits were much appreciated by numerous friends.

\section{Prof. Alexandru Slatineanu}

Prof. Alexandru Slatineanu, a leading Rumanian bacteriologist and hygienist, who died on November 27, 1939, was born at Bucharest on January 5, 1873. He studied medicine in Paris under Berger, Dejerine, Babinski and Metchnikoff, in whose laboratory at the Pasteur Institute he made the acquaintance of his compatriot Prof. Cantacuzène, with whom he was closely associated henceforth: He qualified in 1901 with a thesis on experimental Bacillus pfeiffer septiccemia, for which he received the university medal awarded for theses of outstand. ing merit.

From 1902 until 1912, when he was appointed professor of bacteriology at Jassy, Slatineanu acted as chief assistant to Cantacuzène at Bucharest in his work on experimental medicine and the reorganization of the Rumanian health services. At Jassy he founded an institute of hygiene of which he was made director, and also organized an isolation hospital for infectious diseases. In 1917 he took an active part in the campaign against typhus fever which was then very prevalent in Moldavia. In 1931 he was appointed general secretary of the Rumanian Ministry of Health under Prof. Cantacuzène, who was the minister of that office. He was the author of numerous articles on infectious diseases which were published in French in the Comptes rendus de la Société de Biologie, Bulletin de la Société de Pathologie Exotique, Archives roumains de Pathologie, or in Rumanian in the Revista Stintelor Medicale.

J. D. Rolleston.

\section{Dr. E. M. Mikkola}

Dr. Erkki Mikael Mikkola, geologist of the Geological Commission of Finland, was killed at Taipale on February 13. Mikkola, who was born in 1907, had become a leading authority in Pre-Cambrian geology, possessing an intuitive faculty of seeing through a geological formation, and picturing it correctly in space and time. His scientific studies led him from botany to geography, quaternary geology, tectonics and petrology. His three Lapland maps are given a foremost place among. Pre-Cambrian sheets of the Finnish Geological Survey. Their description in English is a monograph of fundamental value.

When the Russian attack developed on November 30 , Mikkola, as a lieutenant in the reserve, went to join his company, leaving the Geological Survey at Helsinki just one hour before it was destroyed during a bombing raid. Thereafter he spent all his time, two and a half months, in the front lines, taking a full share in the dangers of the heroic defence.

We regret to announce the following deaths:

Prof. C. D. Marx, emeritus professor of civil engineering in Stanford University, on December 31, aged eighty-two years.

Mr. H. C. Newton, first chairman of Messrs. Newton and Wright, Ltd., London, manufacturers of X-ray equipment, on February 19, aged eighty years. 